\title{
Sobre los poetas y la poesía
}

\author{
About poets and poetry \\ Antonio Acevedo Linares \\ Poeta, Ensayista y Sociólogo \\ Magíster en Filosofía Latinoamericana - énfasis en Educación y Filosofía Colombiana \\ Universidad Santo Tomás \\ Especialista en Filosofía Política Contemporánea \\ Universidad de Antioquia \\ antonioacevedolinares@msn.com \\ Artículo recibido el 07 de agosto del 2015 \\ Aprobado el 26 de octubre del 2015
}

Sobre los poetas y la poesia se han escrito muchas cosas bellas y lúcidas, sarcásticas y blasfemas, sobre su oficio y su soledad, su sensibilidad e imaginación, su compromiso y libertad, su pasión o vocación por la poesía, etc.

Federico García Lorca dijo que es difícil ser poeta, es mejor ser farmacéutico. Los verdaderos poetas son videntes dijo Tagore. Jean Cocteau dijo que por definición, el poeta es póstumo. Comienza a vivir después de su muerte y, cuando está vivo, camina con un pie en la tumba. En su Historia Universal de la Infamia, Borges dijo que Jesús se codeó con rameras y poetas y hasta con gente peor. Oscar Wilde dijo que la sociedad perdona con frecuencia al criminal, pero no perdona nunca al soñador. A este respecto todos conocemos lo que dijo John Lennon en su célebre canción Imagine. Puedes decir que soy un soñador pero no soy el único, espero que algún día te unas a nosotros y el mundo vivirá como uno. Nadie cree que la poesía pueda causar daño alguno dijo Willian Blake. Marx Van Doren dijo que la poesía es la forma más concisa de decir las cosas. Sin embargo hay individuos que piensan que la poesía es una forma vaga de hablar. Aldo Pellegrini dijo que la poesía representa el esfuerzo más grande del hombre por comunicarse. La poesía es creación o no es nada dijo Andrés Holguín. El honor de la poesía fue salir a la calle. Fue tomar partido en este combate y en aquél. No se asustó el poeta cuando le dijeron insurgente, la poesía es una insurrección dijo Neruda. 
Ezra Pond dijo no repitas en verso mediocre, lo que ya ha sido dicho en buena prosa. Un poema es la expresión de ideas o sentimientos en un lenguaje que nadie emplea, puesto que nadie habla en verso dijo Pessoa. La poesía está en todo -- en la tierra y en el mar, en el lago y en la margen del río. Está en la ciudad también -- no lo nieguen-aquí donde me siento es para mí evidente: hay poesía en el ruido de los carros en las calles, hay poesía en cada momento o hasta en lo vulgar, ridículo movimiento de un trabajador que, del otro lado de la calle, está pintando el rótulo de una carnicería. Eliot dijo que la poesía no consiste en dar rienda suelta a las emociones, no es la expresión de la personalidad, sino una liberación de la personalidad. Lo que piensas y lo que sientes, esto aún no es poesía dijo Carlos Drummond de Andrade. Según Miguel Ángel Asturias, los indígenas de Guatemala dijeron que la poesía es donde las palabras se encuentran por primera vez. Virginia Woolf dijo ¿estoy condenada a producir asco? ¿Soy poeta? La poesía responde a necesidades esenciales del espíritu humano dijo Rafael Maya. La poesía es todo lo que se mueve. El resto es prosa dijo Nicanor Parra. La poesía es una pipa dijo André Bretón. Henry Miller dijo ser poeta fue en un tiempo la vocación más alta, hoy es la más vana. Y ello no porque el mundo se haya vuelto sordo a la voz del poeta, sino porque el poeta mismo no cree ya en su misión divina. El culto al arte toca a su fin cuando solo existe para un puñado de elegidos. Entonces deja de ser arte para convertirse en un lenguaje cifrado de una sociedad secreta, una logia para propagar una individualidad que ha perdido su sentido.

El poeta aun cuando no escribe también está creando y pensando las cosas que escribirá hasta que estén maduras para convertirlas en palabras, en poemas. El poeta es un visionario a través de lo onírico y de la realidad de su tiempo, y de su imaginación que crea las cosas más reales entre más las imagina. El poder de la poesía es hacer con lo que se imagina las cosas más reales. En la poesía imaginar es crear imágenes con las palabras como se crean imágenes en la mente. La imagen es una representación poética de la realidad. Imaginar es crear dijo Neville Goddard pero en todo caso la poesía no se agota en la imagen. La poesía es mucho más que una bella imagen porque a veces se corre el riesgo de quedarse en las palabras sin transcenderlas y sin un trasfondo filosófico o social o humano que es donde está todo el espíritu humano. Son muchos los recursos que proporciona el lenguaje para escribir pero son las escuelas o las corrientes literarias las que privilegian una u otra forma o estilo literario. Los creadores o los autores no están exentos de esa misma condición o dirección en la literatura. La más bella definición de la poesía es también un poema. Alguien dijo una vez que el día que se comparó a una mujer con una rosa, ese día había nacido la poesía.

Ahora bien, con respecto a los premios a la poesía, a veces ganar un premio literario en Colombia parece que es caer en el desprestigio. La calidad de los textos que se premian contradice a la institución o el jurado que los otorga. A veces los que ganan premios parecen ser los más malos poetas, y parece que hasta ese nivel ha llegado la corrupción de los concursos literarios en Colombia pero por otra parte, la diatriba o la reseña 
parece ser que ha sustituido el ejercicio de la crítica literaria, y hasta la calidad literaria o estética esta deslindada de la calidad humana. No importa ser un bandido si se es un buen poeta. En la poesía cada poeta construye su propio universo pero hay factores extraliterarios que sombrean su obra en tanto que muchos poetas pasan a la historia de la literatura por razones extraliterarias y no tanto como por la belleza de su obra, como por ejemplo, una muerte por tuberculosis en la cárcel, un exilio político, un asesinato prematuro o un premio fraudulento, etc.

El oficio de la poesía es un oficio de la soledad pero de una soledad solidaria porque el poeta no está solo, el poeta esta consigo mismo. Una soledad que se alimenta como cuervos y que le sacaran los ojos, el corazón y la vida. A veces los mejores textos de la poesía no son en verso sino en prosa donde la poesía se filtra con sus encantos y metáforas. El ejercicio de la poesía es un ejercicio de síntesis, de economía del lenguaje pero una de las características de la poesía moderna es su brevedad o su laconismo. Los poetas parecen que estuvieran escribiendo para la gente que vive de prisa como si fueran poemas para leer en el metro o en la cama para antes o después de hacer el amor. Desde siempre se le ha pedido al poeta compromiso, pero el poeta ya está comprometido, con su palabra y consigo mismo, con su oficio y su pasión por la poesía. La poesía en todo caso ya está comprometida con las causas justas de este mundo, pero adherir la poesía a una causa política puede ser ya un desgaste inútil, cuando las causas armadas ya han demostrado su estrepitoso fracaso. En Colombia la lucha armada ha fracasado y la insurgencia, cincuenta años después, no logró consolidar la toma del poder. La negociación política al conflicto armado que vive el país es la única salida política a estas alturas del partido. Sin embargo, a veces el poeta es más útil y eficaz en la trinchera del lenguaje que en las trincheras de las barricadas o el combate, prefiere combatir con las palabras en la combinación de todas las formas de lucha.

La poesía tiene nuevos escenarios como son las redes sociales y los blogs que han contribuido al conocimiento de la poesía y sus poetas a través de las autopistas de la red. Ahora existen más allá de su aldea porque su visibilidad es planetaria. Nunca antes la poesía había llegado tan lejos y tenido tanto lectores, aunque los poetas de la vieja guardia extrañamos las publicaciones impresas en papel, en los libros como en los periódicos y las revistas literarias.

Los poetas surrealistas tenían una poética. Yo escribo para realizarme, para lo que era verdad ya no lo sea dijo Michaux y añade, la poesía es un regalo de la naturaleza, una gracia, no un trabajo. No es la poesía quien debe ser libre, sino el poeta dijo Robert Desnos. Benjamín Pèret dijo que el poeta lucha contra toda opresión, la del hombre por el hombre, y la de su pensamiento por los dogmas religiosos, filosóficos y sociales. Combate para que el hombre alcance un convencimiento siempre perfectible, de sí mismo y del universo. Artaud dijo yo no concibo la obra desligada de la vida. Todo poeta valiente dijo Paul Eluard, tiene el deber de 
abrir un camino tan largo como sea posible para la exaltación humana. La poesía es acción, nunca se deja encadenar por sistemas cerrados. Si la poesía no debe servir al hombre, si no debe ayudarle a liberarse de las violencias interiores, de orden moral, y exteriores, de orden social, entonces no es más que un objeto de diversión, simple entretenimiento dijo Tristan Tzara. La poesía es el espejo borroso de nuestra sociedad dijo Louis Aragón, cada poeta respira sobre ese espejo; su aliento lo empaña de diferente manera. Mi ambición es ser el explorador de lo insólito dijo Philippe Soupault; no sé que hubiese sido de no haber conocido la poesía, sé que es una liberación, que gracias a ella me purifico.

La poesía es una interpretación de la realidad y de la vida, interpreta al hombre en su cotidianidad, en sus amores, fracasos y miserias. La poesía, su escritura, es un acto de resistencia contra la barbarie.

Citar este artículo como: Acevedo, A. (2015) "Sobre los poetas y la poesía”. En: Revista La Tercera Orilla (15). Bucaramanga: Universidad Autónoma de Bucaramanga. 